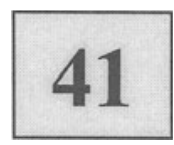

\title{
“MORAL INFRASTRUCTURE” AND VIRTUAL ENTERPRISES: ETHICS AS A COMPETITIVE FACTOR FOR THE INTERNET COMMERCE IN BRAZIL
}

\author{
Armindo dos Santos de Sousa Teodósio \\ Pontificia Universidade Católica de Minas Gerais \\ BRASIL \\ teodosio@gold.com.br
}

\begin{abstract}
The paper debates the ethical challenges of virtual enterprises in Brazil. These questions are linked to the relationship between economic agents in the virtual space. It's important to understand the development of markets in the capitalist system as construction of "moral infrastructures". In the virtual enterprise level this debate reflects about new perspectives of action in the scope of the managerial strategies and behavior of the organizational actors (managers, workers, consumers, ...). In this direction, the ethical reflections in to the business can bring new lights on the challenges that virtual enterprises find in the developing countries as the Brazil.
\end{abstract}

\section{INTRODUCTION}

The paper discusses the challenges and dilemmas of the construction of an ethical reflection and action by the organizations in the "Virtual Economy". It is noticed that the ethical discussion is assuming centrality in the reflections developed in the field of the Management (Brown, 1991), or by the crescent literature dedicated to the theme or even for the great concern of the organizations and of the media with relation to sexual harassment in the work, prejudice for race, gender or ideological option, relationship to organisation-community, control of corruption, among others.

In that scenery, the Virtual Organisations appears in prominence because the great changes that the Internet has generated in the contemporary societies. However, some challenges are really imposed to the effective development of an ethical reflection and action in these organizations (Enriquez, 1997).

For the understanding of the dilemmas and challenges that come, in the beginning it is necessary to rescue the differentiation between the moral concepts and ethics developed by different philosophical currents (Valls, 1987; Vàsquez, 1990). From this what is discussed is the structural that conditions the deepen of the reflection and ethical posture in the contemporary societies, being delimited the 
space and the function of the ethics in the development of the capitalist economical relationships and the obstacles that are imposed due to the capitalist configuration of the last decades (Sen, 1999).

Then an analysis is done on the management in the Virtual Organizations. This contemporary organizations become moralists spaces without, however, support the full development of a posture and an ethical reflection of its members, and above all the one of the managerial staff responsible for the strategic dimensions of the administration.

\section{ETHICS \& BUSINESSES IN THE INTERNET AGE}

Exist some challenges to deepen the ethical reflection inside of the modern organisations, being them big, small or even of the Virtual Organizations. In spite of those challenges and obstacles, what is noticed, more and more, is the centrality of the theme in the proposed discussions in the academic space, for the organisations or for the media of businesses. That tendency has been manifesting itself mainly in the North American organizations, that stand out for the important role as carrying out at the present time as diffusers of new managerial models to the world (Sampson, 1996). A reflex of that is the fact of observing in the context of the American economy, the largest debate on liberty of speech and security, copyrights and free access to the information, privacy and control, amongst other aspects of the Internet universe.

However, it is noticed that in the organizational space the construction of an ethical reflection still shows in a precarious way. In spite of the speech and of the managerial concern with relationship to the linked subjects to the ethics, an ethical reflection and the discussion are not deepened indeed, besides arriving to the point of situations in which it is edged to the rationality lack. An example of that can be verified by the high fear of managers with relationship to processes for sexual harassment in the American organizations. Another example is the quotas in the management for minorities. A lot of times those organizational strategies end up not giving the expected result or even deepening the prejudice that they aim to combat. A mechanical conception of the ethical reflection in the Management field, that doesn't play in the fundamental points of the moral problem in the Virtual Organizations is noticed.

Two questions should be placed before moving forward in that discussion. First: does the Virtual Capitalism need the ethics? Or are ethics and capitalism constituted in opposed poles? Is the second subject sent to the organisational sphere: are the Virtual Companies constituting in global spaces of an ethical reflection and action or in moralist mechanic's spaces?

\section{ETHICS \& MORAL}

A differentiation that should be considered is that ethics and moral are not equivalent terms. The ethics, according to Vàsquez (1990), would be the knowledge field that contemplates the moral. The moral is sent to the mechanisms through them a social group historically determined creates norms of behaviour, sticks or it breaks 
up with those norms and it maintains cohesion by codes of conduct. Making an analogy, it is said that ethics is a circle while the morals is that circle filled out with values and rules of conduct, what would transform it in a sphere. In other words, the moral is historically determined, contingent and determined by groups and societies. The ethics already sends to a wider reflection field. Among the central subjects it is the development of the moral construction among the human societies.

If in the space of the moral, the generalisation becomes complex, in other words, it cannot impose rules of behaviour and values certain person for other ones, in the ethics, a space is opened up to include the social group, through a reflection on the humanity's own characters. According to Ribeiro (1993), the moral determines the best and worst, in other words, makes a dichotomy in the relationships. The ethics already contemplates as the notion is built of the best and the worst among the people and what would be the human being widest aspirations.

\section{VIRTUAL CAPITALISM: ETHICS AS INFRASTRUCTURE?}

The discussion about the relationship between capitalism and ethics won larger breath, mainly, after the experiences of Japanese Management began to call the attention of the western world. The studies that grew on the modus operandi of the Japanese organisations revealed that, in the capitalism developed in that nation, the managerial strategies originating from of the oriental traditional culture, ruled in relationships rigid, big hierarchical loyalty among the organisational actors and in explicit compensations such for the capitalists and managers as for the workers. This pattern would be deeply linked to an ethics of the work based on the Confucianism, a philosophical doctrine that relegates centrality to the work, valuing the discipline, the accomplishment and the systematic effort. The notion that it diffused was the one that it is possible to conciliate capitalism and ethics, and the unfolding of that relationship would bring many benefits, both the social or as a productive economical, having as more significant example as the Japanese experience.

Fonseca (1993) defends the thesis, originating from of Adam Smith, that the progress of the capitalist system is only possible by the creation of what is called "moral infrastructure". In spite of the conception of economical liberalism be one of the most outstanding aspects of Smith's thought, great part of his work discusses the need to grow up rules to regulate the capitalism, relativizing the notion of pure self-regulation of the "invisible hand." Fonseca (1993) it rescues the idea, demonstrating that the ethics should be seen as a production factor, in other words, it is constituted in strategic element that joins efficiency to the capitalist global system.

Observing the historical path of the central capitalist savings, it is verified that this system was only established and dinamized itself in countries us which quite rigid moral rules appeared, that the wild selfishness. For Fonseca (1993), the notions that the capitalism is a true jungle, in which always governs the law of the stronger, and the utilitarian calculation guides the people's action does not have historical reference. As the author, it is verified exactly the opposite, the capitalism is only consolidated in the societies in which was sediment formed the moral infrastructure, or better, the moral foundation deeply. United States, Germany and England would be examples of nations that created very rigid moral norms and that developed dynamic and solid savings. Other countries in which the moral infrastructure did not 
consolidate, and the Latin-American countries (specially Brazil) can be framed in that list, the capitalist system would come, still in the current days, structured in an inconsistent and precarious way.

Weber (1994) is other classic author that studies the connection between the progress of the capitalism and the ethics. According to the author, what is called "Protestant ethics", ruled by the valorisation of the work and of the material accomplishment, but mainly, in codes of conduct quite rigid that was constituted in one of the principal factors for the development of the capitalist system in the nonCatholic countries of western Europe.

Kurz (1997), however, defends the idea that of what is called Confucian Capitalism is a myth. As the author, the idea that in Japan, and also in other societies, a moral capitalism or an ethical one is false. This is due to the fact that deepen of the current capitalism, the traditional cultures are been breaking apart, and with them that loyalty line, of hierarchy, of submission and of the valorisation of the work, in other words, the Confucian Capitalism is collapsing. The author mentions several relative empirical data to the Japanese society that reinforces the argument, such as increase of the index of infantile prostitution and of adult women, financial and political scandals, among others.

Kurz (1997) affirms the moral infrastructure was necessary in the period of appearance of the capitalism. In that phase, the need of basic and universal rules of behaviour was made more intense. But, starting from the moment that the capitalist system settles down and the economy breaks bows feudal, agrarian, archaic and precapitalist, the relationships are going to be passed for the financial, prevailing the dynamics of the market for the access to the goods. The moral infrastructures are not done so necessary. As the author, the manifestation of the ethical sphere in the Japanese economy on that century would feel fundamentally due to the fact of that nation have travelled the most recent path in terms of consolidation of the capitalism.

It's important to note that the Virtual Business is new sphere of action of the contemporary capitalism. In this sphere, the ethics is as a relevant infrastructure factor not only because the Internet business are "young", but because the nature of the capitalistic transactions in this field too. An argument that reinforces the intimate and necessary connection between capitalism and the ethics is presented by Fonseca (1995), when studying what is called economy of the information. The modern society is seen by some authors, among them stands out Drucker (1996), as immersed in the Era of the Knowledge, in which informational patterns would be sent to several spheres of the social coexistence. Observing the dynamics of the economy of the information, according to Fonseca (1995), it is clear the strategic need of a moral infrastructure. An example of that can be observed in the economical agent's case that has the knowledge about the behaviour of the stocks exchange. The probable buyers of that information will only be willing to pay for that information until the moment that don't know it. After your knowledge, those information already lose their strategic value for that group. Then, they have to structure the change relationships based on an intrinsic trust that the information are trustworthy. This kind of economical interaction demands a moral base in your economical agents' behaviour. If this moral base does not exist, change patterns won't be settled down. In this sense, the world crisis of the current capitalism can be 
seen as a crisis of the credibility, in other words, a crisis of this moral infrastructure of the economical system (Sen, 1999).

\section{VIRTUAL ENTERPRISES: LOCUS FOR THE ETHICS?}

And what about the field of the Virtual Organizations, what has been happening now in the companies? The ethical subject is discussed a lot, but actually, the Virtual Organizations constitute a moralist space and not locus of the ethics in itself. In the space of the action and of the organisational strategy a moral discussion is built without a deepen of its ethical dimension, being dissociated in the practice of the organisational speech.

The first point for reflection refers inside to the delimitation of the moralist of the organisations. All of them establish norms of intern conduct, mainly in Virtual Corporations. In that sense, the study of Pagès et al (1979), became a reference work in the organisational studies shows very clearly the creation of codes of conduct inside of the organizations and their similarity with the behaviour patterns demanded by the religion. These norms are found in a more intense way in the manuals than the organization creates, such as operation manuals and even manuals of behaviour. Some of those rules of procedures have the intention to guide strategic decisions in certain situations.

According to Davis (1997), in those manuals and even in the speech propelled for the high dome organisational is noticed a clearly delineated profile of what it would be a "good worker. Among the desired attributes are: the dynamism, the flexibility, the creativity, the capacity to work in a team, the development of the use, among others. This schedule is so extensive, that according to Leite (1991) treats of a true one "superman" in the work.

However, many of the qualities that is demanded to the worker are contradictory to each other. Sennett (1999) affirms that with the coming of new global management models the contradictions are deepened in which it interferes in the managerial group. According to Lima (1995), the worker starts to have to reconcile qualities of difficult consistency to each other, such as being competitive and knowing how to work in group; being enterprising and to submit to the rules of behaviour of the company; to be capable to understand the human being in your deeper dimension, to work effectively and to link very well with the people, and to punish, to dismiss and to make decisions individually when necessary. Vegara \& Branco (1993) increase this schedule with the ability to work with the logic computational, quantitative and financial and to be at the same time capable of understanding the subtileness of the culture of an organization and the abstraction of the feelings among the people (workers, customers, ...).

Besides, other norm of conduct very propelled for the organizations now is sent to the employability. Again reappears the ambiguity of the concept, in the proportion as soon as in that total dedication is demanded at the same time to the professional path around the interests and private motivations. It is added to the fact of assuming the human being as a business opportunity, being the people a product that therefore, has to be presented and sold at the market. That reductionism of the human nature ends strictly for submitting any substantive reflection of the ethics to a dimension instrumental. 
In spite of they establish rigid codes of conduct, in other words, being moralists, the Virtual Organisations develop practices in your day by day that send the relativizing of those norms. A "white strike" it is nothing else than to come true thoroughly what is placed in the manual. In this way, it is noticed that the organisation, as defend Veltz \& Zarifian (1993) is always a construct unfinished, in which several organisational actors are interacted, and declared or established it in the procedures not always reproduces the true dynamics of the action in the work context. In the routine of operations in the daily organizational the reach of goals assumes centrality in detriment of the execution of the procedures in itself.

Being like this, in the daily the workers don't follow the manual precisely, they accomplish what is more appropriate in terms of the strategic consequences considered more important or appropriate. Only in the moment of a flaw, it is used the manual and the regulations are used in order to punish.

\section{RESPONSIBILITY AND CONVICTION IN THE VIRTUAL ORGANISATIONS}

In the space of the ethical reflection there are two basic conceptions. One of them is originating from of the deontology and another of the teleology. Weber (1982) works with that distinction when discussing the politician's ethical context and the intellectual. As the author, the individual can be guided by the ethics of the convictions or for the ethics of the responsibilities. In the ethics of the convictions, the attachment the values and universal norms prevail. In the first, certain values and norms are assumed as universal and worth for any context, society, culture and organization (Srour, 1998).

Another form of ethical reflection, would be guide the rationality not for the universal laws that will govern the behaviour, but for the strategic consequences of the action to be undertaken. A reflection is made on the results of the action to be untaken. In that sense, patterns of conduct defined straightly would not exist at first.

It is noticed that, in the organizational field, the notion of ethics convictions prevails, that shows in the execution of norms and in the conservatism. However, the social actors' behaviour that are inserted in the Virtual Organizations, in other words, employees, customers, suppliers, managers, CEOs, shareholders, among others, is guided by the ethics of the responsibilities. This is justified because, mainly in the daily context of the global societies, the presence of different visions, values, conceptions and cultures in the same social group turn the attachment to rigid universal norms extremely contradictory of the point of view of the social action.

What is noticed is that the Management is ruled by the logic of the control (Morgan, 1986). A basic idea that noticed from the born of the administration is that it shows, although in a covered way, is that to manager is to create controls on the people, so that they behave in a certain way. However, the challenge of the Management is in working with the notion of ethics of the responsibility, because this ethical pattern presupposes that the Virtual Organisations abdicate of the control on the individuals that work in her. Almeida Neto (1998), commenting the Weber's ethics conception, that considers the human being notion from behind the ethics of the responsibility, presupposes that the individual is capable of to discern among what it is right and what is missed in each specific context and making appropriate 
decisions to the expected ethical consequences. In that sense, the ethics of the responsibility presupposes that the people can define coherently a solution for a certain problem.

The challenges of building an ethical reflection incur inside of the largest capacity of diffusion of the ethics of the responsibility of the Virtual Organizations, opening strategic perspectives to work indeed with the people's autonomy. That implicates in doing with that the managerial thought abdicates from its tendency to control the people more and more and to create norms of behaviour (Carneiro, 1995).

There is a diffusion of organizational global politics centred in the ethical subject, but studies demonstrate that the effective strategic incorporation will only consolidate in the proportion that to walk in the sense of the incorporation of that reflection for the social actors that compose the Virtual Organisation and they formulate their own strategic (Stoner \& Freeman, 1992). On the other hand, that will only feel in a more concrete way in the proportion that such individuals are assumed by the managerial models of Virtual Organizations as capable to do strategic choices ethically appropriate, what is sent to the field of the ethics of the responsibilities.

\section{REFERENCES}

1. Almeida Neto, M. A ética no mundo moderno: comentários a partir de Wittgenstein e Weber. Belo Horizonte, Brasil: PUC/MG, 1998.

2. Brown, M. T. Working Ethics: strategies for decision making and organizational responsability. Chicago, IL: Jossey-Bass Inc, 1991.

3. Carneiro, A. M. M. "Teorias organizacionais: do ceticismo à consciência crítica". In: Revista de Administração Pública 1995; 29 (2), 51-70.

4. Davis, W. Great miths of business. London, UK: Kogan Page Limited, 1997.

5. Druker, P. Administrando em tempos de grandes mudanças. São Paulo, BR: Pioneira, 1996.

6. Enriquez, E. “Os desafios éticos nas organizações modernas". In: Revista de Administração de Empresas 1997; 37 (2), 6-17.

7. Fonseca, E. G. As partes \& o todo. São Paulo, BR: Siciliano, 1995.

8. Fonseca, E. G. Vícios privados, benefícios públicos? A ética na riqueza das nações. São Paulo, BR: Companhia das Letras, 1993.

9. Kurz, R. Os últimos combates. Petrópolis: Vozes, 1997.

10. Leite, J. B. D. Treinamento e desenvolvimento de gerentes no Banco do Brasil: uma imagemobjetivo para década de 90. Belo Horizonte, BR: FACE/UFMG, 1991.

11. Lima, M. E. A. Os equívocos da excelência: as novas formas de sedução da empresa. Petrópolis, BR: Vozes, 1995.

12. Morgan, G. Images of organisation. Thousand Oaks, CA: Sage Publications, Inc, 1986.

13. Pagés, M. et al. L'emprise de l'organisation. Paris: Presses Universitaires de France, 1979.

14. Ribeiro, R. J. "Mais 10 Mandamentos". In: Folha de São Paulo 1993; pp. 10, February 14 th,

15. Sampson, A. Company man: the rise and fall of corporate life. São Paulo, BR: Companhia das Letras, 1996.

16. Sen, A. Sobre ética e economia. São Paulo, BR: Companhia das Letras, 1999.

17. Sennett, R. The corrosion of character. Rio de Janeiro, BR: Record, 1999.

18. Srour, R. H. Poder, cultura e ética nas organizações. Rio de Janeiro, BR: Campus, 1998.

19. Stoner, J. A. F. \& Freeman, R. E. Management. Englewood Clifs, NJ: Prentice Hall, 1992.

20. Valls, A. L. M. O que é ética. São Paulo, BR: Ed. Brasiliense, 1987.

21. Vàzquez, A. S. Ética. Rio de Janeiro, BR: Civilização Brasileira, 1990.

22. Veltz, P. \& Zarifian, P. "Vers de nouveaux modèles d'organization?". In: Sociologie du travail 1993; 35 (1), 44-67. 
23. Vergara, S.C. \& Branco, P.D. "Em busca da visão de totalidade". In: Revista de Administração de Empresas 1993, 33(6), 20-31.

24. Weber, M. A ética protestante e espírito do capitalismo. São Paulo, BR: Pioneira, 1994.

25. Weber, M. Ensaios de Sociologia. Rio de Janeiro, BR: Guanabara Koogan S.A., 1982. 